\title{
On the Role of Phosphatidylethanolamine in the Inhibition of Activated Protein C Activity by Antiphospholipid Antibodies
}

\author{
Mikhail D. Smimov, ${ }^{\mathbf{5}}$ Douglas T. Triplett, ${ }^{\ddagger}$ Philip C. Comp, ${ }^{\mathbf{5}}$ Naomi L. Esmon, ${ }^{\mathbf{5 1}}$ and Charles T. Esmon ${ }^{\mathbf{5 1}}$ \\ ${ }^{8}$ Cardiovascular Biology Research Program, Oklahoma Medical Research Foundation, Departments of 'Pathology, 'Biochemistry, and \\ Molecular Biology, and "Medicine, University of Oklahoma Health Sciences Center, and *Howard Hughes Medical Institute, Oklahoma \\ City, Oklahoma 73104; and ${ }^{\ddagger}$ Research Department/Medical Education, Ball Memorial Hospital, Muncie, Indiana 47303
}

\begin{abstract}
Phosphatidylethanolamine (PE) is an important membrane component for supporting activated protein $\mathrm{C}$ anticoagulant activity but has little influence on prothrombin activation. This difference constitutes a potential mechanism for selective inhibition of the protein $C$ anticoagulant pathway by lupus anticoagulants and/or antiphospholipid antibodies. In this study, we demonstrate that the presence of PE augments lupus anticoagulant activity. In the plasma of some patients with lupus anticoagulants, activated protein $\mathrm{C}$ anticoagulant activity is more potently inhibited than prothrombin activation. As a result, in the presence of activated protein $C$ and $P E$, these patient plasmas clot faster than normal plasma. Patients with minimal lupus anticoagulant activity are identified whose plasma potently inhibits activated protein $\mathbf{C}$ anticoagulant activity. This process is also PE dependent. In three patient plasmas, these phenomena are shown to be due to immunoglobulins. The PE requirement in the expression of activated protein $C$ anticoagulant activity and the PE dependence of some antiphospholipid antibodies provide a mechanistic basis for the selective inhibition of the protein $\mathbf{C}$ pathway. Inhibition of activated protein $\mathbf{C}$ function may be a common mechanism contributing to increased thrombotic risk in certain patients with antiphospholipid antibodies. (J. Clin. Invest. 1995. 95:309-316.) Key words: protein $\mathrm{C} \cdot$ thrombosis $\cdot$ lupus anticoagulant $\cdot$ phospholipids $・$ APC resistance
\end{abstract}

\section{Introduction}

Lupus anticoagulants and antiphospholipid antibodies have been the focus of considerable attention recently because the presence of these antibodies is associated with an increased incidence of thrombosis $(1,2)$. Furthermore, patients with antiphospholipid antibodies exhibit increased levels of prothrombin activation fragments, suggesting elevated coagulation even in the basal state (3).

Address correspondence to Charles T. Esmon, Ph.D., Howard Hughes Medical Institute, Oklahoma Medical Research Foundation, 825 N.E. 13th Street, Oklahoma City, OK 73104. Phone: 405-271-7571; FAX: 405-271-3137.

Received for publication 6 April 1994 and in revised form 12 September 1994.

J. Clin. Invest.

(C). The American Society for Clinical Investigation, Inc.

0021-9738/95/01/0309/08 \$2.00

Volume 95, January 1995, 309-316
The mechanism by which these classes of antibodies might influence coagulation has been proposed to involve binding to negatively charged phospholipid membrane surfaces. Antibody binding to membranes may or may not require $\beta 2$ glycoprotein $1(1,4)$. Evidence exists that the antiphospholipid antibodies, usually detected by binding to cardiolipin, can be separated from the lupus anticoagulant antibodies (4). Antiphospholipid antibodies have been reported to require $\beta 2$ glycoprotein 1 to bind to membrane surfaces, whereas no comparable requirement was detected for lupus anticoagulants (4). In contrast, other investigators have identified anticardiolipin antibodies that express anticoagulant activity only in the presence of $\beta 2$ glycoprotein 1 (5). Antibody binding either directly to membranes or mediated by $\beta 2$ glycoprotein 1 may constitute only a subset of the mechanisms involved in modulating coagulation. For instance, other mechanisms that have been proposed to explain inhibition of coagulant and anticoagulant complexes include antibody binding to the prothrombin $(6,7)$, protein $S(7)$ or protein $\mathrm{C}(7)$ membrane complexes.

One of the candidate mechanisms that has been proposed to explain the thrombotic tendencies in these patients involves inhibition of the protein $C$ anticoagulant pathway. Indeed, both protein $C$ activation $(8-10)$ and activated protein C (APC) ${ }^{1}$ anticoagulant activity $(7,11-13)$ have been shown to be partially inhibited by the lupus anticoagulants. Although antibodies to protein components of the pathway contribute in a small number of patients ( see for instance reference 14), most patients appear to exhibit these protein $\mathrm{C}$ pathway inhibitory activities only in the presence of a membrane surface. Selective inhibition of protein $\mathrm{C}$ function on the membrane surface would be expected to be associated with an increased thrombotic risk similar to that observed in patients with decreased protein $\mathrm{C}$ levels (15-17). Although inhibition of these steps in the protein $C$ pathway would contribute to propagation of coagulation, these procoagulant effects would presumably be offset by the anticoagulant effects caused by the antibodies blocking the assembly of the coagulant complexes. Superficially, this situation would appear to mimic the effects of oral anticoagulants in which membrane binding by all of the vitamin $\mathrm{K}$-dependent factors is impaired, the net result of which is inhibition of coagulation. Therefore the question arises as to how selective inactivation of the protein $\mathrm{C}$ pathway can be accomplished by antibodies that appear to function by binding to membrane surfaces.

One possibility is that cell surfaces differ from the phospholipids used in clotting tests with respect to their sensitivity to antiphospholipid antibodies. It has been observed, for instance,

1. Abbreviations used in this paper: APC, activated protein C; PC, phosphatidylcholine; PE, phosphatidylethanolamine; PS, phosphatidylserine; X-CP, factor X-activating enzyme from Russell's viper venom. 
that platelet membrane procoagulant activity is relatively insensitive to the lupus anticoagulants $(18,19)$, and this may limit the anticoagulant effects of these antibodies in vivo. Whether a similar situation exists for APC remains unknown. An alternative and possibly complementary explanation for selective inhibition of the protein $\mathrm{C}$ pathway is that procoagulant and anticoagulant complexes exhibit different membrane requirements. Consistent with this possibility, we demonstrated recently that APC anticoagulant activity was dramatically enhanced by phosphatidylethanolamine (PE) or, to a lesser extent, cardiolipin (20). Both of these phospholipids have been shown by others to be major targets of the antiphospholipid antibodies $(1,21)$, raising the possibility that $\mathrm{PE}$ provides a mechanism for selectively inhibiting the protein $\mathrm{C}$ pathway in patients with antiphospholipid antibodies, even when they exhibit low levels of lupus anticoagulant activity.

In this study, we demonstrate that PE within phospholipid vesicles enhances the lupus anticoagulant activity relative to vesicles devoid of PE but that $\mathrm{PE}$ augments the inhibitory activity toward APC function even more. The net result is that in the presence of APC, plasma from some patients with lupus anticoagulants can actually clot faster than the normal plasma. Some patients with antiphospholipid antibodies and only weak lupus anticoagulant activity also inhibit APC function potently. This response is also dependent on the presence of $\mathrm{PE}$ in the vesicles. The dependence on PE for optimal APC function may provide a molecular explanation for the thrombotic tendency in some patients with lupus anticoagulants and/or antiphospholipid antibodies.

\section{Methods}

\section{Reagents and proteins}

The factor $\mathrm{X}$ activator was purified from Russell's viper venom (Sigma Chemical Co., St. Louis, MO) (X-CP) (22). Human APC (23), and human thrombin (24) were prepared as described. Immunoglobulin ( Ig) from the patient's plasma and the normal pool was isolated by the three step partitioning according to the manufactures instructions (" $E$ Z-Sep;" Middlesex Sciences, Inc., Foxborough, MA). The precipitate was reconstituted to the original volume. When the patient IgG was studied explicitly, this was prepared by purification on a Protein G column (HiTrap, Pharmacia, Uppsala, Sweden) according to the manufacturer's directions. Bovine serum albumin (BSA), gelatin, optical APTT reagent, Ancrod, bovine brain PE, and buffers were from Sigma Chemical Company (St. Louis, MO). Spectrozyme-PCa was from American Diagnostica (Greenwich, CT). 1-Palmitoyl-2-oleoyl phosphatidylserine (PS) and 1-palmitoyl-2-oleoyl phosphatidylcholine (PC) were purchased from Avanti Polar Lipids Inc. (Birmingham, AL).

Liposomes were prepared by sonication of phospholipid mixtures in TBS ( $20 \mathrm{mM}$ Tris- $\mathrm{HCl}$, $\mathrm{pH} 7.4,150 \mathrm{mM} \mathrm{NaCl}, 0.02 \%$ sodium azide) as described (20) and stored at room temperature. PS/PC liposomes contained 20\% PS and 80\% PC. PE/PS/PC liposomes contained $40 \%$ PE, $20 \%$ PS, and $40 \%$ PC.

\section{Plasma}

Normal pooled plasma was prepared by mixing fresh citrated plasma from 14 healthy volunteers and was stored at $-80^{\circ} \mathrm{C}$. The clinical and laboratory evaluations of the patients presented in this paper are summarized in Table I.

\section{Thrombin formation in plasma}

Plasma was defibrinated by adding $5 \mu \mathrm{l}$ of a $50 \mathrm{U} / \mathrm{ml}$ Ancrod solution to $1 \mathrm{ml}$ of citrated plasma for $5 \mathrm{~min}$ at $37^{\circ} \mathrm{C}$, and the fibrin was removed by centrifugation at $8,000 \mathrm{~g}$ for $10 \mathrm{~min}$. The intrinsic pathway was initiated at room temperature by addition of optical APTT reagent consisting of ellagic acid and cephalin. All reactions were performed in wells of a 96-well vinyl assay plate (Costar Corp., Cambridge, MA). The first stage of the reaction, which contained $20 \mu \mathrm{l}$ TBSG (TBS containing $1 \mathrm{mg} / \mathrm{ml}$ gelatin, $\mathrm{pH} 7.4$ ), $10 \mu$ l plasma under investigation, and $10 \mu \mathrm{l}$ optical APTT reagent, was allowed to incubate for $5 \mathrm{~min}$, after which either $10 \mu \mathrm{l}$ of $80 \mathrm{nM}(5 \mu \mathrm{g} / \mathrm{ml})$ human APC (+APC) or $10 \mu \mathrm{l}$ buffer (-APC) and $10 \mu \mathrm{l}$ normal plasma were added and the entire mixture was allowed to incubate for an additional $3 \mathrm{~min}$. Thrombin formation was initiated by addition of $25 \mu \mathrm{l}$ of $20 \mathrm{mM} \mathrm{CaCl}_{2}$. Thrombin formation was stopped at the times indicated by addition of $20 \mu \mathrm{l}$ of $50 \mathrm{mM}$ EDTA, $200 \mathrm{mM}$ Mops, $\mathrm{pH}$ 7.4. Thrombin activity was assayed immediately to prevent the slow inhibition by antithrombins in the plasma. Thrombin activity was determined with the chromogenic substrate, Spectrozyme PCa $(50 \mu \mathrm{l}, 0.5 \mathrm{mM})$ on a $V_{\max }$ kinetic microplate reader (Molecular Devices, Menlo Park, CA). Thrombin concentration was determined by reference to a standard curve prepared with human $\alpha$-thrombin.

\section{Clotting assays}

Clotting assays were performed by a modification of the dilute Russell's viper venom test. Purified factor $\mathrm{X}$-activating enzyme $(\mathrm{X}-\mathrm{CP})$ was used instead of crude venom. The assays were adapted to allow evaluation of the phospholipid or APC dependence of the clotting time.

Phospholipid dependence. Assays were performed in wells of 96well plates. Liposomes in TBSG $(30 \mu \mathrm{l})$ at the concentrations indicated were incubated for $20 \mathrm{~min}$ at room temperature with $10 \mu \mathrm{l}$ of the plasma, serum, or immunoglobulin under investigation. To this sample was added $10 \mu \mathrm{l}$ of $320 \mathrm{nM}$ human APC, $10 \mu \mathrm{l}$ of $10 \mathrm{ng} / \mathrm{ml} \mathrm{X-CP,} \mathrm{and} 10$ $\mu \mathrm{l}$ normal pooled plasma. The entire mixture was incubated for $1 \mathrm{~min}$. Clotting was initiated by addition of $25 \mu \mathrm{l}$ of $20 \mathrm{mM} \mathrm{CaCl}_{2}$. The clotting time was determined on a $V_{\max }$ kinetic microplate reader.

$A P C$ dependence. The assay was performed as above except that the sample under investigation $(10 \mu \mathrm{l})$ was mixed with $30 \mu \mathrm{l}$ APC at the concentrations indicated. After a 5-min incubation, $10 \mu \mathrm{lof} 60 \mu \mathrm{g} /$ $\mathrm{ml}$ phospholipid, $10 \mu \mathrm{l}$ of $10 \mathrm{ng} / \mathrm{ml} \mathrm{X-CP}$, and $10 \mu \mathrm{l}$ normal plasma were added and the entire mixture was incubated for an additional 1 min. Clotting was started by addition of $25 \mu \mathrm{l}$ of $20 \mathrm{mM} \mathrm{CaCl}_{2}$.

\section{Removing of liposome-specific antibodies from $\mathrm{IgG}$}

Adsorption of liposomes on latex. Polystyrene latex pellet, $50 \mu \mathrm{l}$, (diameter $6 \mu \mathrm{m}$, Sigma Chemical Co.) was washed three times with $1 \mathrm{ml}$ TBS by centrifugation $(8000 \mathrm{~g}, 1 \mathrm{~min})$; resuspended in $50 \mu \mathrm{l}$ TBS containing $5 \mathrm{mM} \mathrm{CaCl}{ }_{2}$; mixed with $100 \mu \mathrm{l}$ liposomes $(1 \mathrm{mg} / \mathrm{ml}$ of total phospholipid in TBS); incubated $2 \mathrm{~h}$ on an orbital shaker at $37^{\circ} \mathrm{C}$; pelleted by centrifugation; washed two times with $1 \mathrm{ml}$ of TBS; resuspended in $1 \mathrm{ml}$ TBS containing $1 \mathrm{mg} / \mathrm{ml}$ gelatin, $1 \mathrm{mg} / \mathrm{ml}$ ovalbumin, and $10 \mathrm{mg} / \mathrm{ml} \mathrm{BSA}$; incubated $2 \mathrm{~h}$ at room temperature on a shaker; washed two times with $1 \mathrm{ml} \mathrm{TBS}$; and resuspended in $500 \mu \mathrm{l}$ TBS. ${ }^{14} \mathrm{C}$ $\mathrm{PC}$ incorporated into the liposomes was used to calculate the concentration of adsorbed liposomes. The phospholipid concentration in the final suspension was $50 \mu \mathrm{g} / \mathrm{ml}$ for both PS/PC and PE/PS/PC adsorbed liposomes. Latex-carrying liposomes were stored at $4^{\circ} \mathrm{C}$ for $\geq 7 \mathrm{~d}$ without any loss of adsorbed phospholipid.

Adsorption of liposome-specific antibodies. A 200- $\mu \mathrm{l}$ suspension of liposome-covered latex particles was washed two times with $1 \mathrm{ml}$ TBSG containing $2 \mathrm{mM} \mathrm{CaCl}$. The particles were pelleted and $30 \mu \mathrm{l}$ of 17 $\mathrm{mg} / \mathrm{ml} \mathrm{IgG} \mathrm{from} \mathrm{plasma} \mathrm{C21} \mathrm{was} \mathrm{added,} \mathrm{mixed,} \mathrm{incubated} 40 \mathrm{~min}$ at $25^{\circ} \mathrm{C}$ with periodic mixing, and then filtered through a 4-mm filter (GVMillex, $0.22 \mu \mathrm{m}$, Millipore Corp., Milford, MA) by centrifugation at $3000 \mathrm{~g}$ for $3 \mathrm{~min}$. To avoid loss of material, the pellet on the filter was washed in the centrifuge tube with $65 \mu \mathrm{l}$ TBSG, and both filtrates were combined. The final concentration of $\mathrm{IgG}$ was $5 \mathrm{mg} / \mathrm{ml}$.

\section{ELISA for antiphospholipid antibodies}

The assay was performed as described (25) with minor modifications. Microtiter plate wells (PVC; Costar Corp.) were coated with $50 \mu \mathrm{l}$ PE 
Table I. Characterization of Patients

\begin{tabular}{|c|c|c|c|c|c|}
\hline & Sex/age & Clinical findings/Dx & History of thrombus & LA & $\mathrm{ACA}$ \\
\hline T5 & $\mathrm{F} / 43$ & Primary antiphospholipid antibody syndrome & CVA, 13 RSA & Yes & $\begin{array}{l}\text { High titer IgG } \\
\text { Low titer IgM }\end{array}$ \\
\hline T6 & M/59 & Primary antiphospholipid antibody syndrome & MI/TIA & Yes & High titer IgG \\
\hline $\mathrm{T} 7$ & $\mathrm{M} / 63$ & Vasculitis & $\begin{array}{l}\text { ?TIA } \\
\text { Amaurosis fugax }\end{array}$ & Yes & $\begin{array}{l}\text { High titer IgG } \\
\text { Moderate titer IgM }\end{array}$ \\
\hline $\mathrm{T} 8$ & M/64 & $\begin{array}{l}\text { Secondary APA syndrome/drug induced } \\
\text { (procainamide) }\end{array}$ & - & Yes & Low titer IgG \\
\hline $\mathrm{T} 15$ & $\mathrm{~F} / 15$ & SLE & DVT, Pulmonary emboli & Yes & High titer IgG \\
\hline $\mathrm{T} 20$ & $\mathrm{~F} / 38$ & $\begin{array}{l}\text { Possible primary antiphospholipid antibody } \\
\text { syndrome }\end{array}$ & RSA/TIA & Yes & $\begin{array}{l}\text { High titer IgG } \\
\text { Moderate titer } \operatorname{IgA}\end{array}$ \\
\hline T21 & $\mathrm{M} / 52$ & Primary antiphospholipid antibody syndrome & Arterial/venous thrombosis & Yes & $\begin{array}{l}\text { High titer IgG } \\
\text { Moderate titer IgM } \\
\text { Moderate titer IgA } \\
\text { Moderate titer IgG }\end{array}$ \\
\hline $\mathrm{T} 28$ & $\mathrm{M} / 60$ & Factor VIII inhibitor (autoimmune) & DVT & Negative & Negative \\
\hline T35 & $M / 34$ & Primary antiphospholipid antibody syndrome & DVT & Yes & High titer IgG \\
\hline $\mathrm{C} 1$ & $\mathrm{~F} / 29$ & SLE & Spontaneous abortions & Yes & Low titer \\
\hline $\mathrm{C7}$ & $\mathrm{F} / 18$ & SLE & DVT, thrombophlebitis & Yes & High titer \\
\hline $\mathrm{C} 13$ & $F / 20$ & SLE & DVT & Yes & High titer \\
\hline $\mathrm{C} 21$ & $F / 34$ & SLE & Kidney thrombosis & Yes & Moderate titer \\
\hline
\end{tabular}

$C V A$, cerebrovascular accident; RSA, recurrent spontaneous abortions; $M I$, myocardial infarction; TIA, transient ischemic attack; DVT, deep vein thrombosis; $S L E$, systemic lupus erythematosus; $A P A$, antiphospholipid antibodies.

or a mixture of phospholipids containing $40 \% \mathrm{PE}, 20 \% \mathrm{PS}$, and $40 \%$ PC (total concentration $50 \mu \mathrm{g} / \mathrm{ml}$ ) dissolved in ethanol. Control wells to determine nonspecific binding were treated only with ethanol. After a 1-h incubation at room temperature, the ethanol was evaporated under vacuum for $3 \mathrm{~h}$ at room temperature. Nonspecific binding was minimized by coating the wells for $2 \mathrm{~h}$ with $10 \mathrm{mg} / \mathrm{ml}$ BSA in TBS. Plasma, IgG, and conjugate of goat anti-human IgG + IgM with peroxidase were diluted in the same buffer with $2 \mathrm{mM} \mathrm{CaCl}$. All incubations were for $1 \mathrm{~h}$, and the plates were washed with TBS containing $1 \mathrm{mg} / \mathrm{ml} \mathrm{BSA}$ and $2 \mathrm{mM} \mathrm{CaCl}_{2}$.

\section{Factor $V$ determination}

Factor V/Va was measured by a one-stage assay as described (26). One unit of factor $\mathrm{V}$ is defined as the activity present in $1 \mathrm{ml}$ of normal plasma.

\section{Results}

To test the hypothesis that lupus anticoagulants could actually favor the net coagulant response in the presence of APC, thrombin generation was measured in normal plasma and the plasma of a patient with lupus anticoagulant activity in the presence and absence of APC (Fig. 1). The coagulation cascade was initiated in defribinated plasma with ellagic acid and cephalin. Brain cephalin is a crude preparation containing many phospholipid species, including $\sim 40 \%$ PE. As expected, thrombin generation in the absence of added APC was faster in the control than in the lupus anticoagulant patient's plasma. The lupus anticoagulant patient's plasma exhibited a marked lag before thrombin formation ensued. In the presence of APC, the thrombin generation began sooner in the lupus anticoagulant plasma than in the normal control, that is, the reverse of what was seen in the absence of APC. In normal plasma, thrombin formation was blocked over the time period tested. In lupus anticoagulant plasma in the presence of APC (Fig. 1, open diamonds), thrombin formation clearly began earlier than in normal plasma (open circles) under identical conditions. Furthermore, APC had relatively little effect on the time course of thrombin generation in the patient's plasma (compare the open and closed diamonds for the lupus plasma to the open and closed circles for the normal plasma).

To test the hypothesis that this effect was dependent on specific membrane phospholipid components, we compared the clotting times of plasma samples using liposomes composed of $20 \%$ phosphatidylserine and $80 \%$ phosphatidylcholine with those containing $40 \%$ PE, 20\% PS, and 40\% PC. PE was chosen as the phospholipid of choice for comparison since it is a major

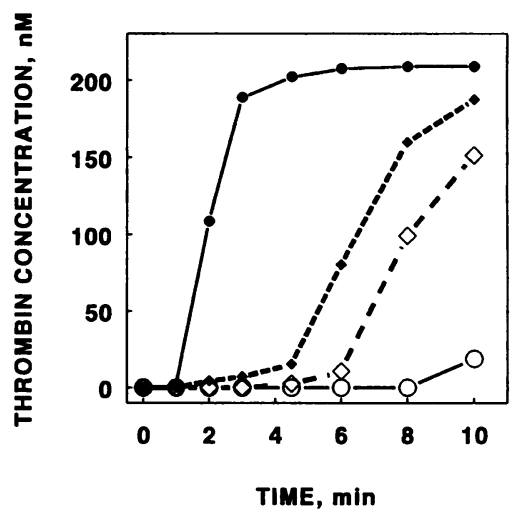

Figure 1. The influence of APC on the time course of thrombin formation in defibrinated plasma from normal donors and a patient $(\mathrm{C} 1)$ with a lupus anticoagulant. Thrombin formation was monitored in the presence and absence of $5 \mathrm{nM}$ APC in plasmas treated with ellagic acid and cephalin as described in Methods. Normal plasma without $(\bullet)$

or with ( $(5) 5 \mathrm{nM}$ APC. Plasma from a patient, $\mathrm{Cl}$, with a lupus anticoagulant without $(\diamond)$ and with $(\diamond) 5 \mathrm{~nm}$ APC. 


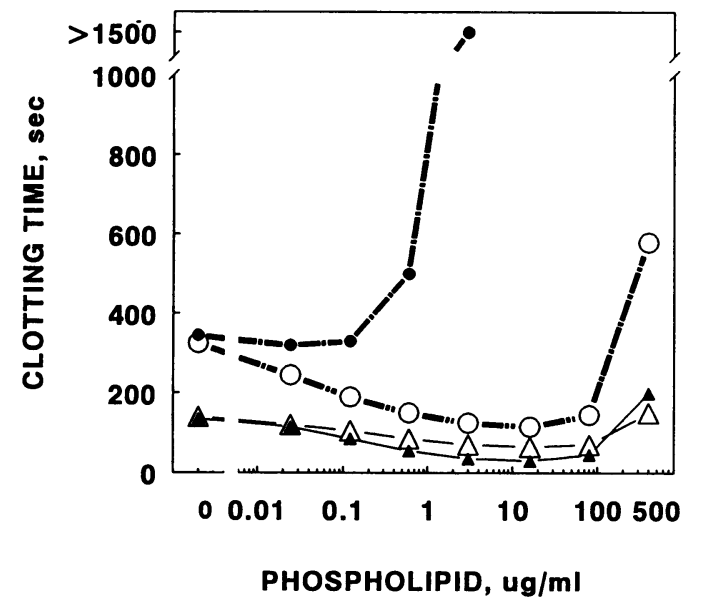

Figure 2. The influence of PE on the phospholipid dependence of coagulation in the presence and absence of APC in normal plasma. Coagulation was initiated with $\mathrm{X}-\mathrm{CP}$ as described in Methods. The clotting times with $\mathrm{PE} / \mathrm{PS} / \mathrm{PC}$ liposomes without $\mathrm{APC}(\Delta)$ and with $30 \mathrm{nM}$ APC $(\bullet)$. The clotting times with PS/PC liposomes without $(\Delta)$ and with $30 \mathrm{nM} \mathrm{APC} \mathrm{(O).}$

component of the surface of the outer phospholipid leaflet after platelet activation (27), it is a major phospholipid in brain and hence in cephalin, it is required for optimal APC function (20), and it can interact with lupus anticoagulant antibodies (21). Before comparing the response of the lupus patient plasmas, however, it was useful to compare the role of membrane composition on the dose-response relationships of clotting times of normal plasma in the presence and absence of APC (Fig. 2). For these experiments, clotting was initiated with X-CP since with this enzyme the phospholipid composition and concentration could be varied independently. Increasing the phospholipid concentration decreased the clotting time in the absence of APC whether or not the vesicles contained PE. At very high concentrations, the vesicles inhibited clotting. In the presence of APC, PE-containing vesicles exhibited a much greater anticoagulant response at all vesicle concentrations, illustrating the anticoagulant activity associated with the PE-containing vesicles.

We next compared the coagulation profiles of several patients with lupus anticoagulants (Fig. 3). To aid in the analysis of this complex comparison among patients and conditions, the particular reaction conditions and symbols corresponding to the comparisons of interest are presented in the text below as well as in Fig. 3. The studies were performed in the presence ( $C$ and $D)$ and absence $(A$ and $B$ ) of APC. For these studies, coagulation was supported on vesicles with $(B$ and $D)$ and without ( $A$ and $C$ ) PE. As anticipated, in the absence of APC, the plasmas containing lupus anticoagulants (open symbols, $A$ and $B$ ) had longer clotting times than the normal plasma (closed circles) at all concentrations of both types of vesicles. The lupus anticoagulant plasmas exhibited longer clotting times with the PE-containing vesicles (open symbols, $B$ compared with $A$ ). In the presence of APC, when clotting was performed on vesicles lacking PE $(C)$, the clotting times of the lupus anticoagulant plasma were similar to or longer than that of the normal plasma pool. In contrast, on PE-containing vesicles in the presence of APC $(D)$, several of the patient plasma samples actually clotted faster than the normal plasma, especially at the higher phospho-

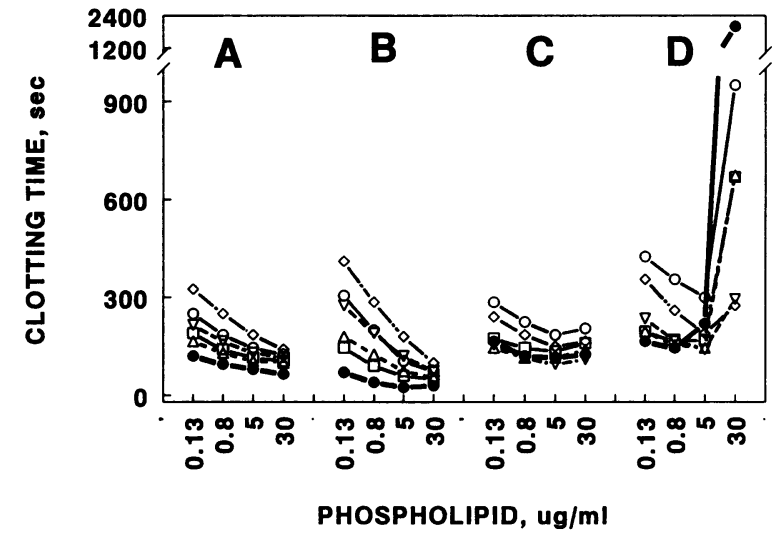

Figure 3. The influence of PE on the ability of lupus anticoagulants to impair APC anticoagulant activity. Coagulation was initiated with X$\mathrm{CP}$ and the assays were performed as described in Methods. ( $A$ ) PS/ PC liposomes without APC; $(B)$ PE/PS/PC liposomes without APC; (C) PS/PC liposomes with $60 \mathrm{nM}$ APC; $(D) \mathrm{PE} / \mathrm{PS} / \mathrm{PC}$ liposomes with $30 \mathrm{nM}$ APC. Normal plasma $(\bullet)$; patient C7 $(0)$; patient T5 $(\triangle)$; patient T6 $(\nabla)$, patient T7 $(\diamond)$; patient T8 $(\square)$. The higher levels of APC used in the samples with PS/PC liposomes were to allow anticoagulant function to be observed.

lipid concentrations. For example, the patients represented by the inverted triangles and open diamonds (Fig. $3 \mathrm{D}$ ) clotted six times faster than the control plasma at $30 \mu \mathrm{g} / \mathrm{ml}$ phospholipid.

These studies raised the question of whether potent inhibitory activity toward APC might also be found in samples with low lupus anticoagulant activity. In Fig. $4 \mathrm{~B}$, several patient plasmas (open symbols) inhibited APC anticoagulant activity very effectively compared with the control (closed circles). These samples showed only marginally increased clotting times in the absence of APC. In A, patient plasmas with prolonged clotting times in the absence of APC had a general tendency to clot faster than the control plasmas at high levels of APC.

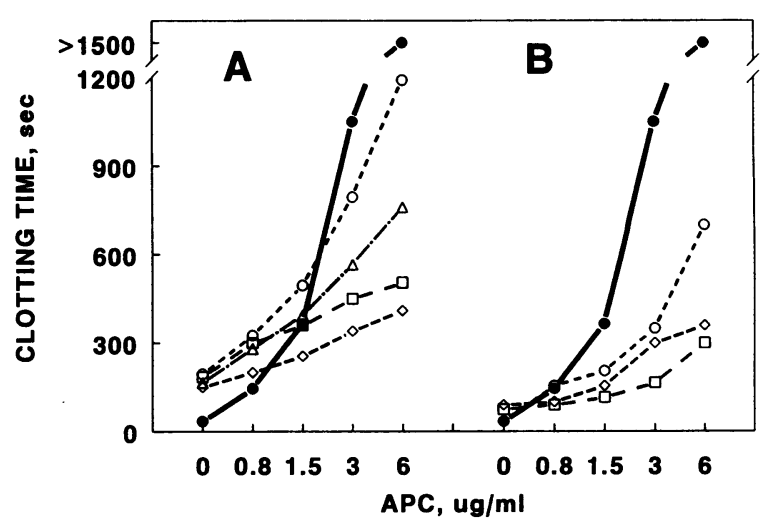

Figure 4. The inhibitory activity toward APC anticoagulant activity is poorly correlated with lupus anticoagulant activity when analyzed as a function of APC concentration. These assays were initiated with X-CP and were performed at $6 \mu \mathrm{g} / \mathrm{ml} \mathrm{PE} / \mathrm{PS} / \mathrm{PC}$ (for details, see Methods). $(A)$ Patients with high lupus anticoagulant activity: normal plasma $(\bullet)$, patient C7 $(O)$, patient T20 $(\diamond)$, patient T21 ( $\square)$, patient T35 $(\Delta)$. $(B)$ Patients with low lupus anticoagulant activity: normal plasma $(\bullet)$, patient T28 (O); patient C13 $(\triangle)$, patient T15 ( $\square)$. 


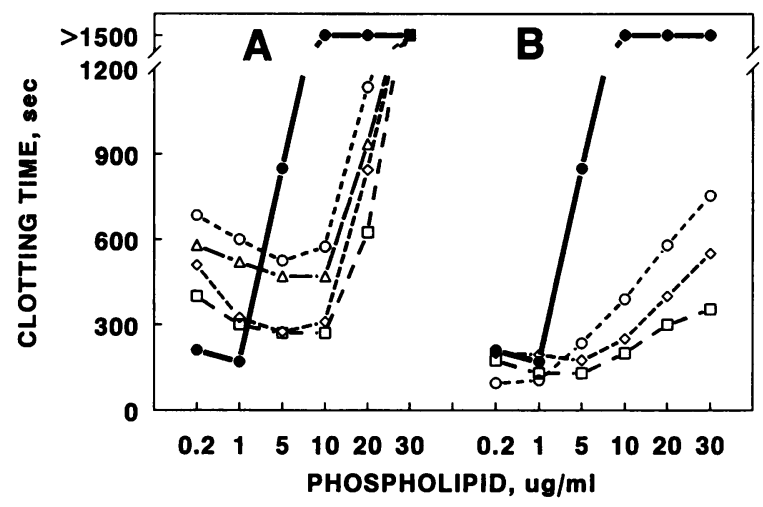

Figure 5. The inhibitory activity toward APC anticoagulant function is poorly correlated with lupus anticoagulant activity when analyzed as a function of phospholipid concentration. The assays were initiated with $\mathrm{X}-\mathrm{CP}$ in the presence of $30 \mathrm{nM}$ APC. (A) Patients with high lupus anticoagulant activity: normal plasma $(\bullet)$, patient $\mathrm{C} 7(O)$, patient T20 $(\diamond)$; patient T21 $(\square)$; patient T35 $(\Delta)$. (B) Patients with low lupus anticoagulant activity: normal plasma $(\bullet)$; patient T28 (O); patient $\mathrm{C} 13$ $(\diamond)$; patient T15 ( $\square)$.

Some of the patient plasmas with either high or low lupus anticoagulant activity could effectively block APC anticoagulant activity when analyzed as a function of increasing phospholipid concentration at constant APC (Fig. 5). In Fig. $5 \mathrm{~A}$, the patient plasmas (open symbols) with high lupus anticoagulant activity clotted slower than the control (closed circles) at low phospholipid but faster than the control at high phospholipid concentrations (closed circles). Some of the patients who exhibited little lupus anticoagulant activity blocked APC anticoagulant activity effectively at most of the phospholipid concentrations tested (Fig. $5 \mathrm{~B}$ ). The patient results shown in Figs. 4 and 5 are representative of some of the highest APC inhibitory activity that we have observed. Thus patients can possess potent inhibitory activity toward APC even when they have only modest levels of lupus anticoagulant activity.

Recently, familial APC resistance that is associated with thrombotic tendency has been described (28-30) and has been shown to be due to an abnormal factor $\mathrm{V}$ that lacks cofactor activity (31). The cofactor activity of the factor $\mathrm{V}$ was lost after activation (31). If the activity that we report here was due to an abnormal factor $\mathrm{V}$, then the activity would be anticipated to be lost in serum. Plasma was incubated with thrombin (10 $\mathrm{U} / \mathrm{ml}$ ) at $37^{\circ} \mathrm{C}$ for $18 \mathrm{~h}$, and the clot was removed by centrifugation for $15 \mathrm{~min}$ at $10,000 \mathrm{~g}$. Patient serum (C7) was virtually indistinguishable from plasma when assayed in the phospholipid dependence assay (Fig. 6). Both the anti-APC functional activity (Fig. $6 \mathrm{~A}$ ) and lupus anticoagulant activity (Fig. $6 \mathrm{~B}$ ) were retained in the serum. Since factor $\mathrm{Va}$ is not functional in correcting APC resistance and is unstable in serum, it would seem extremely unlikely that this activity could be due to factor V.

The central hypothesis of this paper is that the activity is due to antibodies in the patients plasma. Total immunoglobulins were isolated from normal plasma and patient plasma (C7 and C13). The resultant immunoglobulins had $<0.001 \mathrm{U} / \mathrm{ml}$ Factor $\mathrm{V}$ activity, yet retained both the ability to inhibit APC anticoagulant activity and their lupus anticoagulant function (Fig. 7).

Although the above studies indicate that inhibition of APC anticoagulant function is a property of the patient's immuno-

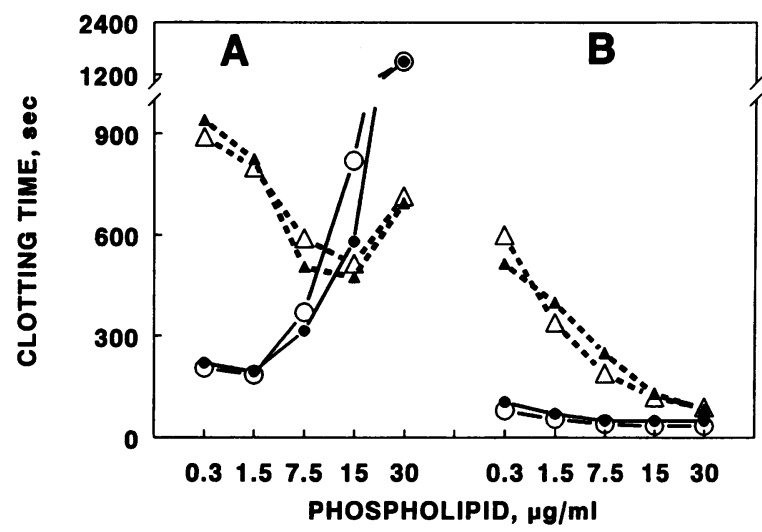

Figure 6. Serum retains plasma lupus anticoagulant and anti-APC activity. The assay was performed as described in Fig. 5 using PE/PS/PC vesicles. (A) With $30 \mu \mathrm{M}$ APC; $(B)$ without APC. Normal plasma (O); serum from normal plasma $(\bullet)$; plasma from patient $C 7(\triangle)$; serum derived from the plasma of patient $\mathrm{C7}(\boldsymbol{\Lambda})$.

globulins, they do not directly deal with the mechanism of inhibition of APC anticoagulant function. One possibility is that the antibodies bind to APC or protein S directly and thus block APC anticoagulant activity. To test this possibility, we established an ELISA for anti-APC and anti-protein S antibodies. ELISA plates were coated with $50 \mu \mathrm{l}$ of $20 \mu \mathrm{g} / \mathrm{ml}$ APC, protein $\mathrm{S}$, or prothrombin. We failed to detect specific antibodies in plasmas, immunoglobulins, or IgG prepared from patients $\mathrm{C}$, C7, C13, C21, or normal plasma. Plasma from patient C7 had low binding to all vitamin $\mathrm{K}$-dependent protein tested. IgG from this patient exhibited a very low binding activity only to human prothrombin (data not shown). These studies suggest antibodies to APC and protein S are not likely to be responsible for inhibition of APC anticoagulant function.

Our assay shows that both lupus anticoagulant and inhibition of APC functional activity are very dependent on the presence

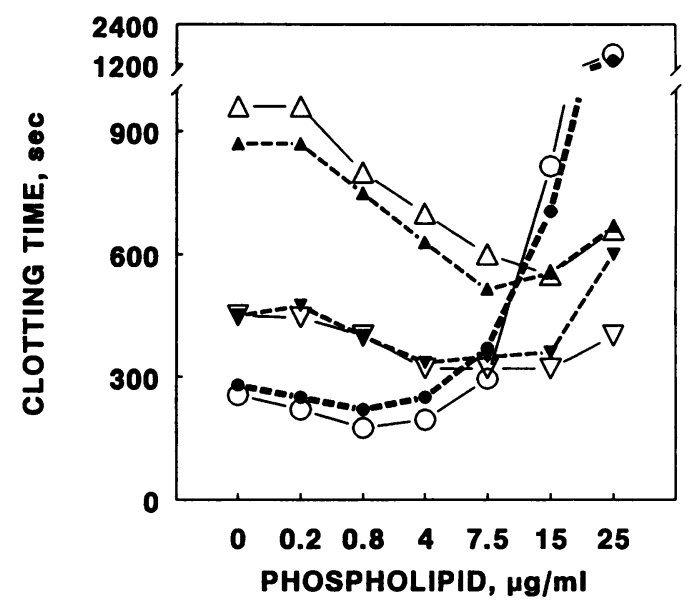

Figure 7. Immunoglobulins retain the lupus anticoagulant and inhibitory activity toward APC function. The assay was performed as described in Fig. 5 using PE/PS/PC liposomes. Normal plasma (O); immunoglobulin from normal plasma $(\bullet)$; plasma from patient $\mathrm{C} 7(\Delta)$; immunoglobulin from patient $\mathrm{C} 7(\Lambda)$; plasma from patient $\mathrm{C} 13(\nabla)$, immunoglobulin from patient $\mathrm{C} 13(\boldsymbol{\nabla})$. 


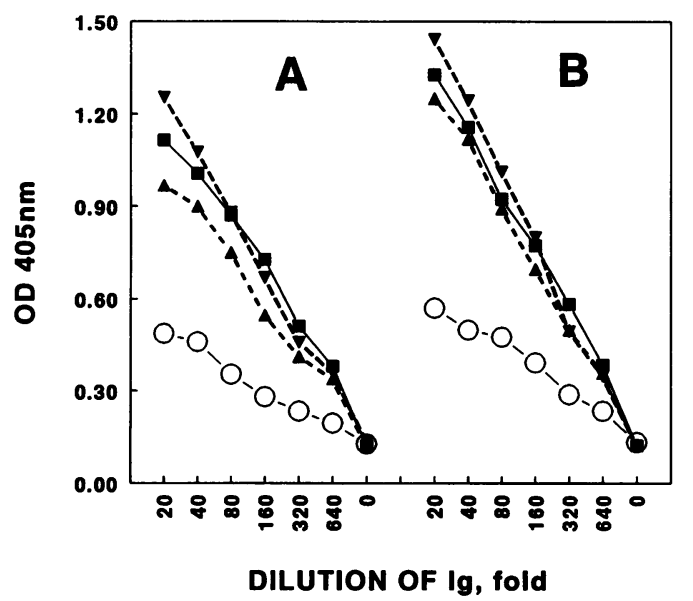

Figure 8. Immunoglobulins from lupus anticoagulant patient plasma bind to PE and PE/PS/PC in ELISA. The assay was performed as described in Methods. $(A)$ Wells coated with PE; $(B)$ wells coated with $\mathrm{PE} / \mathrm{PS} / \mathrm{PC}$. $\bigcirc, \mathrm{Ig}$ from normal plasma; $\Delta, \mathrm{Ig}$ from plasma $\mathrm{Cl} ; \boldsymbol{\nabla}, \mathrm{Ig}$ from plasma $\mathrm{C} 7$; $\mathbf{n}$ Ig from plasma $\mathrm{C} 13$.

of PE in the phospholipid. To test whether the patient antibodies could react directly with PE-containing phospholipids, we established an ELISA in which the plates were coated with PE or mixtures of PE/PS/PC. All patient's plasmas tested, C1, C7, and $\mathrm{C} 13$ (Fig. 8, closed symbols), contained antibodies against PE itself (Fig. $8 \mathrm{~A}$ ) and the mixture of phospholipids, equivalent to PE/PS/PC liposomes (Fig. $8 \mathrm{~B}$ ). These findings indicate that at least this cohort of patients have antibodies that bind to PE. This specificity could allow the antibodies to interfere with APC binding to the membranes, but the observation that the antibodies bind to membranes does not directly demonstrate that this population of antibodies is responsible for inhibiting APC anticoagulant activity.

To address the question of whether the antibodies that inhibit APC anticoagulant function can bind directly to PE-containing phospholipid vesicles, we attempted to adsorb patient IgG with vesicles containing PE and, as a control, with vesicles lacking PE. To minimize the amount of patient IgG required, we performed the adsorption with liposomes on polystyrene latex particles. Vesicles adsorbed on the latex particles still exhibited the same functional characteristics as the vesicles before adsorption, that is, PE still augmented APC-dependent factor $\mathrm{Va}$ inactivation to the same extent (data not shown). The particles allowed rapid removal of the phospholipids with any adsorbed IgG. IgG from patient C21 partially inhibited APC anticoagulant activity (Fig. 9, open squares) compared with IgG from normal plasma (open circles). Adsorption of the patient IgG with PS/PC did not remove the inhibitory activity toward APC function (Fig. 9, closed squares). In contrast, adsorption of the same IgG with PE/PS/PC eliminated almost all of this inhibitory activity (Fig. 9, closed circles), resulting in an IgG fraction with properties almost identical to immunoglobulin purified from normal plasma (open circles). Adsorption of normal IgG with PS/PC- or PE/PS/PC-containing liposomes had no influence on the assay (data not shown). These results suggest that, at least in this patient, the inhibitory IgG can bind to PE-containing vesicles.

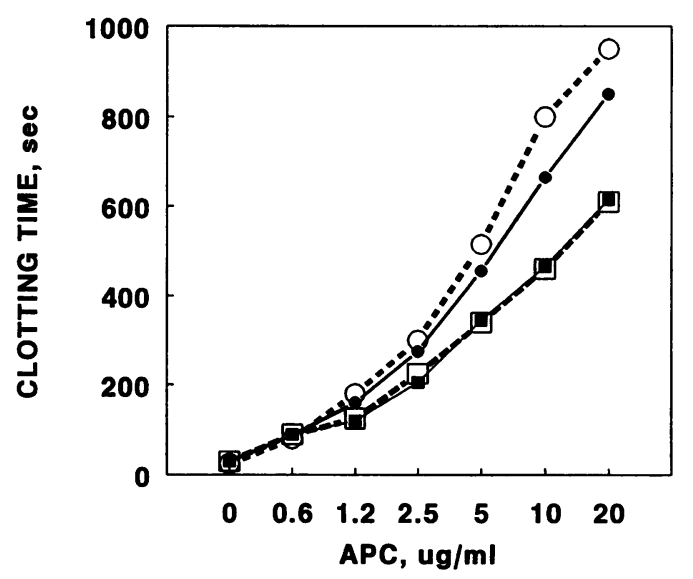

Figure 9. PE-containing liposomes adsorb antibodies with inhibitory activity toward APC. The assay was performed as described in Fig. 4, using $6 \mu \mathrm{g} / \mathrm{ml} \mathrm{PE} / \mathrm{PS} / \mathrm{PC}$ liposomes and $0.5 \mathrm{mg} / \mathrm{ml} \mathrm{IgG}$. $\bigcirc$, IgG from NP; $\square$, IgG from plasma C21; •, IgG from plasma C21, adsorbed on PE/PS/PC liposomes; $\square$, IgG from plasma C21, adsorbed on PS/PC liposomes. For details, see Methods.

\section{Discussion}

In this study we observed that plasma from patients with antiphospholipid antibodies can preferentially inhibit APC function but that, in general, they do so only on vesicles that contain PE. The basis of the selective inhibition of APC function seems likely to reside in the combined observations that a high preponderance of antiphospholipid antibodies bind preferentially to PE and cardiolipin and PE is a more important component of the APC anticoagulant complex than of the procoagulant complexes. Thus, many conditions exist where the potent anticoagulant effects of APC are virtually eliminated by the antiphospholipid antibodies. Although previous studies have shown that lupus anticoagulants can inhibit factor Va inactivation by APC (13), none of the studies has provided a basis for a net procoagulant effect. Indeed, in a recent report published after we completed the present study, inhibition of APC anticoagulant function was observed in APTT assays in many patients with lupus anticoagulants. They also observed that the magnitude of the lupus anticoagulant activity correlated poorly with the inhibition of APC anticoagulant function (32). These results are in essential agreement with our findings. Several groups have also focused on the frequency of antibodies reacting with $P E$ in patients with thrombosis and/or lupus anticoagulants $(25,33-35)$. These studies have concluded that antibodies reacting to $\mathrm{PE}$ are associated with increased risk of thrombosis and/or contribute to the lupus anticoagulant activity. The unusual situation in which the membrane component essential for optimal expression of anticoagulant activity is also the target of the antiphospholipid antibodies provides a rational explanation for the ability of membrane binding antibodies to favor coagulant over anticoagulant reactions. Consistent with this hypothesis, several of the patients had modest to low lupus anticoagulant activity yet inhibited APC function very effectively. This potent inhibition required the presence of $P E$ in the vesicles.

The exact mechanisms by which the antiphospholipid antibodies inhibit APC anticoagulant activity remain to be established. It is clear, however, that the inhibitory IgG from at least 
one patient can bind directly to PE-containing phospholipids but not to PS/PC-containing phospholipids. It is likely that this class of antibodies competes with APC for membrane binding or interferes with the specific PE-dependent APC functions. Based on studies of others, however, at least some antibodies preferentially interact with APC-membrane complexes (7). Since potent inhibitory activity toward APC function was observed only in the presence of PE-containing vesicles, it would appear that even with the latter class of inhibitory antibodies, PE must play a role in recognition by the antibodies.

These studies provide the basis for a potential diagnostic approach to detecting patients at risk of thrombosis and a means to monitor therapy of patients with antiphospholipid antibodies. Evaluation of the relationship between PE-dependent anti-APC activity and thrombotic risk is in progress. Preliminary results support the tentative conclusion that high anti-APC activity in the absence of potent lupus anticoagulant activity may be a risk factor, but further studies are required to confirm this hypothesis. Indeed, patient T15, C13, and T28 all had a history of thrombosis, but other patients have been observed with similar inhibitory activity that do not have a history of thrombosis. Patient T28 is particularly interesting and possibly reflects the physiological significance of inhibiting APC function. Patient T28 is a hemophiliac who developed an acquired factor VIII inhibitor, but, subsequently, after the factor VIII inhibitor titer decreased, the patient experienced thrombotic complications. If these antiphospholipid antibodies that inhibit APC function ultimately prove to correlate well with thrombotic tendency, then the antiphospholipid-dependent APC resistance should be considered in addition to protein $\mathrm{C}$ deficiency, protein $\mathrm{S}$ deficiency, and APC resistance due to abnormal Factor $\mathrm{V}$ as a risk factor for thrombosis.

A physiological role for $\mathrm{PE}$ in the anticoagulant reactions is certainly feasible since in addition to phosphatidylserine, full activation of platelets with potent agonists (e.g., thrombin and collagen ) can result in the outer leaflet of the platelet containing nearly $40 \%$ PE (27). Therefore, the presence of PE on membranes that are involved in coagulation has been documented. The potential specificity of lupus anticoagulants for PE has been validated in at least one study in which human monoclonal antibodies were prepared from the lymphocytes of a patient, and these antibodies all exhibited a high degree of specificity toward PE (21), especially in the hexagonal phase. It remains to be seen whether these observations will aid in identifying patients whose antibody titers and specificities contribute to a high thrombotic risk.

\section{Acknowledgments}

We thank Jeff Box and Clendon Brown for protein preparation, Toppy Nelson for excellent technical assistance, and Julie Wiseman for assistance in preparation of the manuscript.

This research was supported by a George and Francis Ball Foundation grant (D. Triplett) and National Institutes of Health grant HL30443 (P. Comp). Charles Esmon is an investigator of the Howard Hughes Medical Institute.

\section{References}

1. Triplett, D. A. 1993. Antiphospholipid antibodies and thrombosis. A consequence, coincidence, or cause? Arch. Pathol. Lab. Med. 117:78-88.
2. Mueh, J. R., K. D. Herbst, and S. I. Rapaport. 1980. Thrombosis in patients with the lupus anticoagulant. Ann. Intern. Med. 92:156-159.

3. Ginsberg, J. S., C. Demers, P. Brill-Edwards, M. Johnston, R. Bona, R. F. Burrows, J. Weitz, and J. A. Denburg. 1993. Increased thrombin generation and activity in patients with systemic lupus erythematosus and anticardiolipin antibodies: evidence for a prothrombotic state. Blood. 81:2958-2963.

4. Shi, W., B. H. Chong, and C. N. Chesterman. 1993. $\beta_{2}$-Glycoprotein I is a requirement for anticardiolipin antibodies binding to activated platelets: differences with lupus anticoagulants. Blood. 81:1255-1262.

5. Galli, M., P. Comfurius, T. Barbui, R. F. A. Zwaal, and E. M. Bevers. 1992. Anticoagulant activity of $\beta 2$-glycoprotein 1 is potentiated by a distinct subgroup of anticardiolipin antibodies. Thromb. Haemostasis. 68:297300 .

6. Bevers, E. M., M. Galli, T. Barbui, P. Comfurius, and R. F. A. Zwaal. 1991. Lupus anticoagulant IgG's (LA) are not directed to phospholipids only, but to a complex of lipid-bound human prothrombin. Thromb. Haemostasis. 66:629-632.

7. Oosting, J. D., R. H. W. M. Derksen, I. W. G. Bobbink, T. M. Hackeng, B. N. Bouma, and P. G. de Groot. 1993. Antiphospholipid antibodies directed against a combination of phospholipids with prothrombin, protein $\mathrm{C}$, or protein S: an explanation for their pathogenic mechanism? Blood. 81:26182625 .

8. Comp, P. C., L. E. DeBault, N. L. Esmon, and C. T. Esmon. 1983. Human thrombomodulin is inhibited by IgG from two patients with non-specific anticoagulants. Blood. 62:309. (Abstr.)

9. Cariou, R., G. Tobelem, C. Soria, and J. Caen. 1986. Inhibition of protein $\mathrm{C}$ activation by endothelial cells in the presence of lupus anticoagulant. $N$. Engl. J. Med. 18:1193-1194.

10. Freyssinet, J., M. L. Wiesel, J. Gauchy, B. Boneu, and J. P. Cazenave. 1986. An IgM lupus anticoagulant that neutralizes the enhancing effect of phospholipid on purified endothelial thrombomodulin activity - a mechanism for thrombosis. Thromb. Haemostasis. 55:309-313.

11. Borrell, M., N. Sala, C. de Castellarnau, S. Lopez, M. Gari, and J. Fontcuberta. 1992. Immunoglobulin fractions isolated from patients with antiphospholipid antibodies prevent the inactivation of factor $\mathrm{Va}$ by activated protein $\mathrm{C}$ on human endothelial cells. Thromb. Haemostasis. 68:268-272.

12. Simioni, P., A. Lazzaro, S. Zanardi, and A. Girolami. 1991. Letter to the editor: Spurious protein $\mathrm{C}$ deficiency due to antiphospholipid antibodies. Am. J. Hematol. 36:299-300.

13. Marciniak, E., and E. H. Romond. 1989. Impaired catalytic function of activated protein C: a new in vitro manifestation of lupus anticoagulant. Blood. 74:2426-2432.

14. Oosting, J. D., K. T. Preissner, R. H. W. M. Derksen, and P. G. de Groot. 1993. Autoantibodies directed against the epidermal growth factor-like domains of thrombomodulin inhibit protein C activation in vitro. Br. J. Haematol. 85:761 768.

15. Preissner, K. T. 1990. Biological relevance of the protein $\mathrm{C}$ system and laboratory diagnosis of protein $\mathrm{C}$ and protein $\mathrm{S}$ deficiencies. Clin. Sci. (Lond.). 78:351-364.

16. Alving, B. M., and P. C. Comp. 1992. Recent advances in understanding clotting and evaluating patients with recurrent thrombosis. Am. J. Obstet. Gynecol. 167:1184-1191.

17. Reitsma, P. H., S. R. Poort, F. Bernardi, S. Gandrille, G. L. Long, N. Sala, and D. N. Cooper. 1993. Protein C deficiency: a database of mutations. For the Protein C \& S Subcommittee of the Scientific and Standardization Committee of the International Society on Thrombosis and Haemostasis. Thromb. Haemostasis. 69:77-84.

18. Thiagarajan, P., S. S. Shapiro, and L. deMarco. 1980. Monoclonal immunoglobulin M lambda coagulation inhibitor with phospholipid specificity. Mechanism of a lupus anticoagulant. J. Clin. Invest. 66:397-405.

19. Shapiro, S. S., and P. Thiagarajan. 1982. Lupus anticoagulants. Prog. Hemostasis Thromb. 6:263-285.

20. Smirnov, M. D., and C. T. Esmon. 1994. Phosphatidylethanolamine incorporation into vesicles selectively enhances factor $\mathrm{Va}$ inactivation by activated protein C. J. Biol. Chem. 269:816-819.

21. Rauch, J., M. Tannenbaum, H. Tannenbaum, H. Ramelson, P. R. Cullis, C. P. S. Tilcock, M. J. Hope, and A. S. Janoff. 1986. Human hybridoma lupus anticoagulants distinguish between lamellar and hexagonal phase lipid systems. J. Biol. Chem. 261:9672-9677.

22. Esmon, C. T. 1973. The function of factor $\mathrm{V}$ in prothrombin activation. Dissertation. Washington University, St. Louis, MO. 128-140.

23. Esmon, C. T., N. L. Esmon, B. F. Le Bonniec, and A. E. Johnson. 1993. Protein C activation. Methods Enzymol. 222:359-385.

24. Owen, W. G., C. T. Esmon, and C. M. Jackson. 1974. The conversion of prothrombin to thrombin. I. Characterization of the reaction products formed during the activation of bovine prothrombin. J. Biol. Chem. 249:594-605.

25. Falcon, C. R., A. M. Hoffer, and L. O. Carreras. 1990. Evaluation of the 
clinical and laboratory associations of antiphosphatidylethanolamine. Thromb. Res. 59:383-388.

26. Kappeler, R. 1955. Das verhalten von factor V im serum unter normalen und pathologischen bedingungen. Z. Klin. Med. 153:103-113.

27. Bevers, E. M., P. Comfurius, and R. F. A. Zwaal. 1983. Changes in membrane phospholipid distribution during platelet activation. Biochim. Biophys. Acta. 736:57-66.

28. Dahlbäck, B., M. Carlsson, and P. J. Svensson. 1993. Familial thrombophilia due to a previously unrecognized mechanism characterized by poor anticoagulant response to activated protein $\mathrm{C}$ : prediction of a cofactor to activated protein C. Proc. Natl. Acad. Sci. USA. 90:1004-1008.

29. Griffin, J. H., B. Evatt, C. Wideman, and J. A. Fernández. 1993. Anticoagulant protein $\mathrm{C}$ pathway defective in majority of thrombophilic patients. Blood. 82:1989-1993.

30. Svensson, P. J., and B. Dahlbäck. 1994. Resistance to activated protein C as a basis for venous thrombosis. $N$. Engl. J. Med. 330:517-522.

31. Dahlbäck, B., and B. Hildebrand. 1994. Inherited resistance to activated protein $\mathrm{C}$ is corrected by anticoagulant cofactor activity found to be a property of factor V. Proc. Natl. Acad. Sci. USA. 91:1396-1400.

32. Bokarewa, M. I., M. Blomback, N. Egberg, and S. Rosen. 1994. A new variant of interaction between phospholipid antibodies and the protein $\mathrm{C}$ system. Blood Coagul. \& Fibrinolysis. 5:37-41.

33. Berrard, M., M. C. Boffa, M. Karmochkine, M. F. Aillaud, I. JuhanVague, C. Frances, P. Cacoub, J. C. Piette, and J. R. Harle. 1993. Plasma reactivity to hexagonal II phase phosphatidylethanolamine is more frequently associated with lupus anticoagulant than with antiphosphatidylethanolamine antibodies. $J$. Lab. Clin. Med. 122:601-605.

34. Karmochkine, M., P. Cacoub, J. C. Piette, P. Godeau, and M. C. Boffa. 1992. Antiphosphatidylethanolamine antibody as the sole antiphospholipid antibody in systemic lupus erythematosus with thrombosis. Clin. Exp. Rheum. 10:603-605

35. Staub, H. L., E. N. Harris, M. H. Khamashata, G. Savidge, and G. R. V. Hughes. 1989. Antibody to phosphatidylethanolamine in a patient with lupus anticoagulant and thrombosis. Ann. Rheum. Dis. 48:166-169. 